\title{
Biocidal effect of Ergosterol-Propyl Ester Isolated From Ruta angustifolia (Pers.) on Spodopetra littoralis (Boisd.)
}

\author{
Mohamed G. M. Salama ${ }^{1}$, Hala M. I. Mead ${ }^{1}$, \\ Hend M. Sabry ${ }^{1}$, Ahmed H. A. Abo-Ghalia ${ }^{2}$ and Fayez M. M. Semida ${ }^{2}$. \\ ${ }^{1}$ Pest Physiology Department, Plant Protection Research Institute, A.R.C., Giza. \\ ${ }^{2}$ Zoology Department - Faculty of science, Suez Canal University.
}

\begin{abstract}
The toxic effects of some Ruta angustifolia extracts as a bio agent to control Spodoptera littoralis were investigated. Based on $\mathrm{LC}_{50}$ values, the acetonic extract was more effective than hexane and ethyl alcoholic ones. Ergosterol-propyl ester was isolated from the acetonic crud extract by thin layer chromatography and identified using Infra-Red spectrophotometer, Mass Spectrum and evaluated as a fraction for its larvicidal, biological, ultrastructure and biochemical effects on $4^{\text {th }}$ instar $S$. littoralis larvae. The most prominent biological effects were presented as: prolongation in the total larval duration and a decrease in the percentages of survived larvae. The adult emergence percentages, longevity, fecundity, hatchability were significantly decreased compared to controls. Also, some deformation symptoms were recorded in larvae, pupae and adults. The ultrastructure alterations in S. littoralis 4th instar larvae were observed in cuticle microfilament in muscle myofilaments compared to control. Biochemical responses of the $4^{\text {th }}$ instar $S$. littoralis larva has a decreas in the activities of both ALT and chitinase and elevation in AST of supernatant S. littoralis larvae compared to control.
\end{abstract}

Keywords: Ergosterol-Propyl Ester, Enzymes, Ruta angustifolia, Spodoptera littoralis, Ultrastructure.

\section{INTRODUCTION}

Cotton leaf worm, Spodopetra littoralis (Boisd.) (Lepidoptera: Noctudiae) is a high harmful serious damages to more than 112 plant species belongs to 44 different families. Cotton is the main host plant in Egypt; moreover, the pest damage is extended to be seen on many other crops. The insect attacks a wide variety of vegetables, field crops, fruit orchards and ornamental plants at the different growth stages causing serious damage and yield reduction (Khedr et al., 2002). The massive application of pesticides resulted in foundress of pest resistance to these poisons and adverse effects on environment that include acute and chronic hazards to human and non-target organisms, environmental pollution and upsetting the natural balance. Most botanical insecticides are specific, with a save effect on beneficial natural enemies and provide residue-free food and safe environment. So, using botanical insecticides among integrated pest management programms can greatly reduce the use of synthetic insecticides (Hikal et al., 2017).

Ruta species have received a growing attention as a source of pesticide active secondary metabolite such as phenolic, terpenoids, coumarins and alkaloids, which it has biological activities, including antifungal, antioxidant, phytotoxic, and anti-inflammatory activities (Gonzalez-Trujano et al., 2006 and Raghav et al., 2006). Ruta angustifolia (Pers.) (Sapindales: Rutaceae) is used for medicinal and culinary purposes since ancient times. It is normally grows in mountainous areas. It is also cultivated as a pot plant in Malaysia and occasionally in Vietnam and Java for medicinal purposes, and commonly used to cure cramps, flatulence and fever. In Indonesia, $R$. angustifolia has been known as traditional medicine for liver disease and jaundice, where it contains coumarin, alkaloid and flavonoid compounds (Wahyuni et al., 2014). Ruta angustifolia Pers. has been traditionally used for various medicinal purposes. One of the common ethno pharmacological uses includes usage in treatment of cancer by the Chinese community, Malaysia and Singapore (Stella and Richardson 2018).

The current study is an attempt to test a new compound which has an insecticidal activity (ergosterolpropyl ester), isolated from the acetonic extract of $R$. angustifolia on $S$. littoralis to suppress the damage via ultrastructure, biological and biochemical studies.

\section{MATERIALS AND METHOD}

\section{Plant Collection}

Seeds of Ruta angustifolia (Pers.) were from the Department of Horticulture, Faculty of AgricultureZagazig University; then planted in a private property $\left(350 \mathrm{~m}^{2}\right)$ in local gardens at Abu Hammad Sharquia, Egypt. Leaves of $R$. angustifolia (Pers.) were collected at the flowering stage (blossoming periods) during May, 2016.

\section{Preparation of plant material}

The freshly collected leaves were washed with distilled water and spread to dry at normal room temperature for 40 days in the shade. Upon drying, the leaves were pounded using mortar and pestle into smaller particles and then blended to powder. The powder was stored in airtight containers and kept under normal room temperature until required.

\section{Extraction procedure}

Leaves of $R$. angustifolia were extracted at room temperature successively using serial of solvents (hexane, acetone and ethanol 70\%), depending on its polarity. Serial exhaustive extraction were used starting with non-polar solvent to a moderate polar and finally polar solvents hexane, acetone and ethanol 70\%) 
respectively. Sample of $1000 \mathrm{gm}$ powder was soaked in $2000 \mathrm{ml}$ of the first solvent (hexane) for $72 \mathrm{hrs}$. The combined extract was filtered concentrated by rotary evaporator (Model 349/2, Corning Limited). The biomass was dried and subsequently subjected to extraction with another solvent (acetone and ethanol $70 \%)$. The same precedent extraction was used. The crude extracts were weighed and kept in deep freezer until use.

Rearing technique of the cotton leafworm culture, S. littoralis (Boisd.)

A laboratory strain of cotton leaf worm, S. littoralis was reared away from any insecticidal contamination at the division of Cotton Leafworm Department, Branch of Plant Protection Research Institute at Zagazig, Sharquia Governorate, under constant condition $27 \pm 2^{\circ} \mathrm{C}$ and $70 \pm 5 \%$ R.H. to obtain insect culture used in the present investigation according to El-Defrawi et al., (1964).

Application technique for toxic effects of some $\boldsymbol{R}$. angustifolia extracts against the 4th instar larvae of S. littoralis

The toxic effects of tested concentrations against newly molted $4^{\text {th }}$ instar larvae of $S$. littoralis were measured using the leaf dip technique. Larvae were starved for $4 \mathrm{hrs}$ before treatment (Merdan 1968).

Mortality percentages were recorded after $72 \mathrm{hrs}$ for all tested plant extracts and corrected according to Abbott's formula (1925). The lethal concentration (LC) value was evaluated and a toxicity line was illustrated using log-Probit software program Ldp Line ${ }^{\circledR}$ model "Ehabsoft" (Bakr 2000) Toxicity Index and Relative Potency calculated according to Sun equation's (1950):

Toxicity index $=$

$$
\frac{\text { LC50 or LC90 of the efficient compound }}{\text { LC50 or LC90 of the other compound }} \times 100
$$

Separation and purification of isolated compound from acetonic extracts using preparative TLC

The most toxic extract (acetonic extract of $R$. angustifolia) was separated using preparative (Thin Layer Chromatography) TLC $(20 \times 20) \mathrm{cm}$ prepared according to the method of Kirchner (1967) with 1mm thick. The previous plates were air dried for several hours and activated at $105^{\circ} \mathrm{C}$ for $60 \mathrm{~min}$. The concentrated fractions were applied to the chromate-plates as bands with a simple syringe and developed with chloroform, petroleum ether with ratio (3:2), as a solvent system. After the development and drying, bands were detected with UV light (254 and $365 \mathrm{~nm}$ ). The adsorbent containing the bands was scraped off with a razor blade andextracted with pure acetone. Acetone extract of $R$. angustifolia yielded eight main bands on TLC.

Toxicity tests of the eight isolated compounds against $S$. littoralis $4^{\text {th }}$ instar larvae

Toxicity experiment was conducted to estimate the $\mathrm{LC}_{50}$. Four concentrations $(1,2,3$ and 5\%) were used against the $4^{\text {th }}$ instar larvae of $S$. littoralis. The mortality rates were recorded after $72 \mathrm{hrs}$ of treatments and corrected to the positive control values to avoid any effect that may be caused by the solvent used in each treatment. Identification of empirical formula and structure of isolated compound

The toxic compound of $R$. angustifolia was conducted to Infra-Red Spectrometric analysis (IR) and Mass Spectrometric analysis (MS) to determine the chemical structure of the isolated compound.

\section{Biological attributes of ergosterol-propyl ester compound against $\boldsymbol{S}$. littoralis}

The previous procedure of leaf dipping technique was also applied to assess the biological activity of $\mathrm{LC}_{50}$ of ergosterol-propyl ester compared to negative and positive control against newly molted the $4^{\text {th }}$ instar larvae of $S$. littoralis laboratory strain at $27 \pm 2{ }^{\circ} \mathrm{C}$, $70 \pm 5 \%$ relative humidity, with a 14:10 light: dark cycle. Larvae were starved for 4-6 hours before treatment (Merdan, 1968).

Leaf disks $(3 \mathrm{~cm} 2)$ of the fresh castor bean leaves, $R$. communis with a cork borer, were dipped in $\mathrm{LC}_{50}$ for $10 \mathrm{sec}$. Control disks were dipped in distilled water (negative control) and other dipped in acetone solvent (positive control). The treated leaf disks were left to dry then offered to the larvae at the rate of (10 disk/10 larvae) of S. littoralis.

Ten replicates were made for ergosterol-propyl ester and controls (5 larvae / replicate). Filter paper was put upon the bottom to absorb any excess moisture. The larvae were allowed to feed on treated disks for $48 \mathrm{hrs}$ then on untreated leaves until pupation. Fresh castor leaves were provided to the larvae daily. The accumulated feces and debits were removed out daily.

The following measurements were recorded: larval duration and mortality percentages of larvae; adult emergence percentage; deformation in larvae, pupae and adults. Adult longevity, pre, ovi and post-position periods, number of eggs laid/female (fecundity), and hatchability percentages of deposited eggs were also recorded.

\section{Ultrastructure studies}

Ultra structure sections were made for the cuticle and muscles for $4^{\text {th }}$ instars larvae after three days of treating with $\mathrm{LC}_{50}$ of ergosterol-propyl ester in comparison with positive control. Stained sections examined with a JEOL 1010 Transmission Electron Microscope at the Regional Center for Mycology and Biotechnology (RCMB), Al-Azhar University.

\section{Biochemical tests \\ Preparation of samples for biochemical assay}

Healthy samples of the laboratory $4^{\text {th }}$ instar $S$. littoralis larvae, that were treated with $\mathrm{LC}_{50}$ of the ergosterol-propyl-ester, comparing to controls (-ve and + ve). All groups were group homogenized in distilled water $(50 \mathrm{mg} / 1 \mathrm{mg})$ using chilled glass Teflon tissue homogenized (ST-2 Mechanic precisian, pland) surrounded with crushed ice jacket for three minutes. The homogenate samples were centrifuged at $8000 \mathrm{rpm}$ for 
15 minutes. The deposits were used to determine total lipids. Supernatants were referred as enzyme extracts. All the samples were transferred to cleaned screwcapped tubes and stored frozen at $-20 \mathrm{C}$ until using for the biochemical assays. The activities of aspartate aminotransferase (AST), alanine aminotransferase (ALT), and chitinase were also determined.

\section{Determination of transaminase enzymes (AST and} ALT) activities

Enzymes are given a code number, according to (Moss 1992) such as EC 2.6.1.1 (aspartate aminotransferase (AST/ GOT) and EC 2.6.1.2 (alanine aminotransferase (ALT/ GPT) enzyme activities. AST and ALT enzyme activities were determined calorimetrically according to the method of (Reitman and Frankle 1957).

\section{Determination of chitinase activity}

The chitinase (EC 3.2.1.14) assay was carried out according to the method described by Monreal and Reese (1969) with modifications by Shindia et al., (2001) and El-Sayed (2008).

\section{Statistical analysis}

The obtained data were subjected to analysis of variance (ANOVA), using the software package Costat ${ }^{\circledR}$ statistical software (2005) a product of Cohort Software, Monterey, California, USA. The significance of variation treatments was evaluated by Duncan's multiple rang test $(\mathrm{P}<0.05)$ (Snedecor and Cochran 1980).

\section{RESULTS}

Toxic effects of some $R$. angustifolia extracts against the $4^{\text {th }}$ instar $S$. littoralis larvae

The toxic effects of different tested extracts of $R$. angustifolia against the $4^{\text {th }}$ instar larvae of $S$. littoralis were assessed after 72 hrs. of treatments. The $\mathrm{LC}_{50}$ and $\mathrm{LC}_{90}$ values were $(8.77$ and $63.95 \%)$ followed by hexane extract gave 10.94 and $67.00 \%$, respectively. Meanwhile, ethyl alcohol extract gave 17.95 and $82.81 \%$. The 4 th instar larvae of S. littoralis was high susceptible for $R$. angustifolia acetone extract than other organic solvent extracts.

\section{TLC technique for fractionation and purification}

Thin layer chromatography (TLC) was used for the separation and purification of crude acetonic extract. Acetone extract of $R$. angustifolia yielded eight main bands on TLC by developing system consisted of chloroform, petroleum ether at rate of (3:2), respecttively. The compounds were extracted and purified.

\section{Identification of the most effective isolated comp- ound of ergosterol-propyl ester}

Isolated compound was identified using Infra-Red spectrophotometer (IR) and Mass Spectrum (MS) with the help of mass bank of North American. Identifications were made by comparison to spectra in the Wiley 275.1 and NIST 98 (National Institute of Standard and Technology, Gaithersburg, MD, USA) libraries.The pure compound is present in the form of amber yellow resin. It displays that Rf. 0.175 on TLC using solvent system chloroform, petroleum ether with ratio $(3: 2)$, respectively.

The IR spectrum of the compound shows a broad peak at, $3440.09 \mathrm{~cm}-1$ stretching for bounded hydroxyl group absorption and $1728.87 \mathrm{~cm}-1$ stretching for carboxylic group $(\mathrm{C}=\mathrm{O})$. It also, exhibit absorption at 2966.95, 2925.48 and $2876.31 \mathrm{~cm}-1$ indicating the aliphatic structure (C-C) and weak peak at $1642.09 \mathrm{~cm}$ 1 indicated for $(\mathrm{C}=\mathrm{C})$ structure (Figure 1).The MS spectrum in (Figure 2), manifestation the following fragments expressed as $\mathrm{m} / \mathrm{z}$ (\% relative abundance) respectively 421 (46), 375 (52), 363 (100), 317(60), 305 (72), 259 (16), 247 (28), 175 (15), 116 (31), 113 (14) and $59(89 \%) \mathrm{m} / \mathrm{z}$.

Confirmation of structure and mass similarity the comparative library using mass bank-data base found that structure of compound is ergosterol with propyl ester (in the side chain) which are illustrated as follows, the parent ion at $452 \mathrm{~m} / \mathrm{z}$ when, the loss of $\mathrm{CH}_{4}$ followed by carbon atom showed peaks at (433 and 421$) \mathrm{m} / \mathrm{z}$. the loss formic acid confirmed by the peak at $375 \mathrm{~m} / \mathrm{z}$ due to basic structure of steroid.

Toxic effect of ergosterol-propyl ester against the $4^{\text {th }}$ instar $S$. littoralis larvae

The $\mathrm{LC}_{50}$ and $\mathrm{LC}_{90}$ values were 18.83 and $148.9 \%$ for the 4th instar larvae of $S$. littoralis treated with ergosterol-propyl estar.

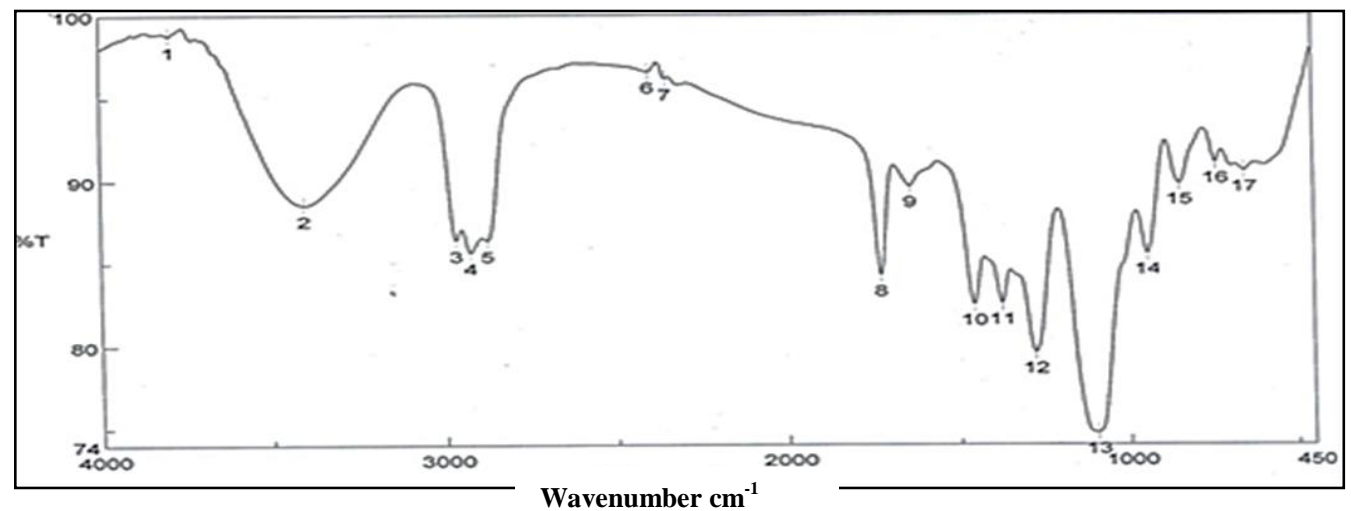

Figure (1): Infra-Red spectrophotometer of ergosterol-propyl ester. 


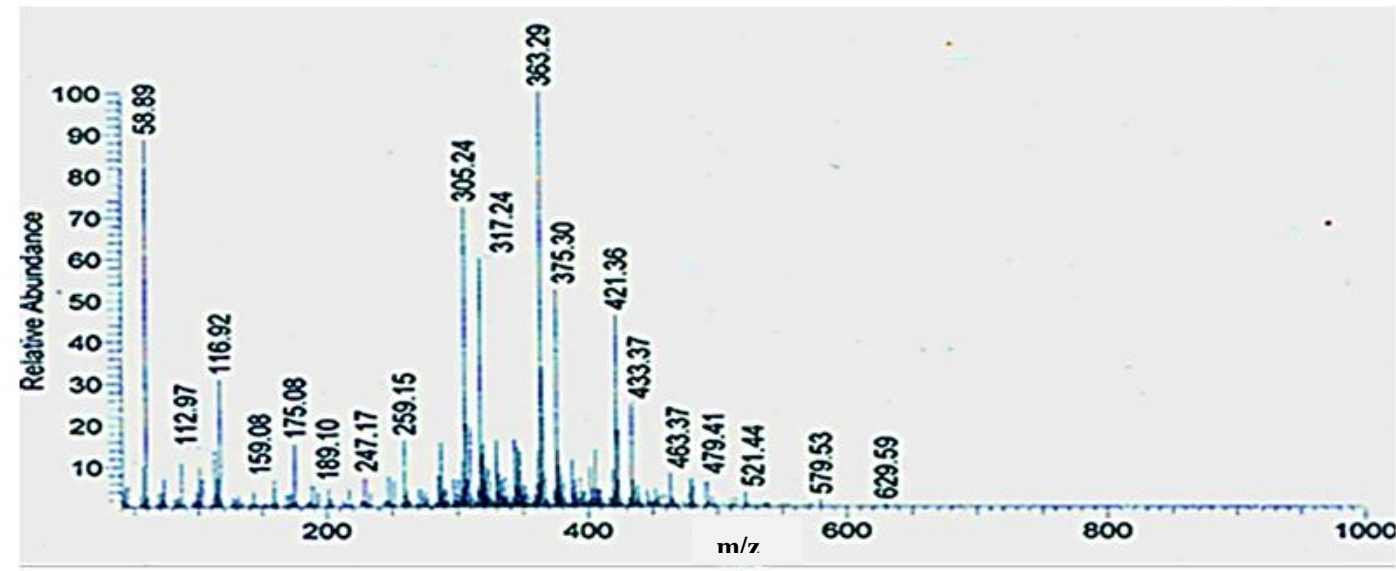

Figure (2): Mass Spectrum of ergosterol-propyl ester.

\section{Impact of ergosterol-propyl estar on some biological attributes of $S$. littoralis}

\section{Effect on larval stage}

Data concerning all the larval stage affected with the tested isolated compound (ergosterol-propyl ester) is tabulated in Table (1). It is clear that all treatments caused highly significant retardation in the total larval duration in different larval instars (13.46 \pm 0.35 days) Controls (-ve and +ve) recorded $11.51 \pm 0.12$ and $11.56 \pm 0.09$ days, respectively (F 2, $6=25.05, P<$ $0.001)$. The larval mortality percentages was recorded
(34.0\%) for ergosterol-propyl ester, while (-ve and +ve) cont-rols did not give any mortality Table (1).

\section{Effect on adult stage}

Highly significant differences on longevity of males were noticed between treatment and control. Data in Table (2) show that, the tested treatment seemed to decrease male longevity than control. Ergosterol-propyl ester give highly significant decreased in longevity $8.83 \pm 0.12$ days, while controls (-ve and +ve) lived $9.36 \pm 0.06$ and $9.40 \pm 0.05$ days, respectively $(\mathrm{F}(2,6=13.56, P<0.005)$.

Table (1): Biological aspects of $S$. littoralis larvae after treated with the isolated compound.

\begin{tabular}{|c|c|c|c|c|c|c|}
\hline \multirow[b]{2}{*}{ Treatments } & \multicolumn{5}{|c|}{ Larval stage/days \pm S.D. } & \multirow{2}{*}{$\begin{array}{c}\text { larval } \\
\text { mortality } \\
\% \\
\end{array}$} \\
\hline & 4th instar & 5th instar & 6th instar & Pre-pupa & $\begin{array}{c}\text { Total larval } \\
\text { duration }\end{array}$ & \\
\hline Control (-ve) & $2.56 \pm 0.09^{b}$ & $2.96 \pm 0.07^{\mathrm{b}}$ & $4.56 \pm 0.07^{\mathrm{b}}$ & $1.43 \pm 0.07$ & $11.51 \pm 0.12^{b}$ & 0 \\
\hline Control (+ve) & $2.6 \pm 0.06^{\mathrm{b}}$ & $3 \pm 0.06^{\mathrm{b}}$ & $4.53 \pm 0.07^{b}$ & $1.43 \pm 0.03$ & $11.56 \pm 0.09^{b}$ & 0 \\
\hline $\begin{array}{l}\text { Ergosterol-propyl } \\
\text { ester. }\end{array}$ & $3.03 \pm 0.09^{\mathrm{a}}$ & $3.7 \pm 0.12^{\mathrm{a}}$ & $5.06 \pm 0.09^{\mathrm{a}}$ & $1.66 \pm 0.09$ & $13.46 \pm 0.35^{\mathrm{a}}$ & 34 \\
\hline L.S.D0.05 & 0.274 & 0.29 & 0.257 & 0.23 & 0.765 & \\
\hline $\boldsymbol{P}$ & 0.0104 & 0.0013 & 0.0039 & $0.076^{\mathrm{ns}}$ & 0.0012 & \\
\hline $\mathbf{F}$ & 10.764 & 24.368 & 16.066 & 4.083 & 25.053 & \\
\hline
\end{tabular}

Control (-ve), (treated with H2O; Control (+ve), treated with acetone; Treatment at the level of LC50.

Data expressed as Mean \pm Standard Error (SE); Treatment at the level of $\mathrm{LC}_{50}$.

Means under each variety sharing the same letter are not significantly different at $P<0.05$.

Longevity of female moth that includes (pre oviposition, oviposition and post oviposition period) were tabulated in Table (2). Ergosterol-propyl ester compound was caused non-significant reduction in female longevity estimated by $8.03 \pm 0.03$ days, compared to -ve control that recorded $8.06 \pm 0.03$ days.

The total number of eggs laid/female moth (Fecundity) resulted from larvae treated with all tested compound revealed highly significant decrease clarified in Table (2). The reduction in the number of eggs/female treated with ergosterol-propyl estar was $1653.1 \pm 50.23 \mathrm{egg}$ laid/female, while for controls (-ve and $+v e$ ) recorded $2016.7 \pm 27.06$ and $1989.1 \pm 32.63 \mathrm{egg}$ laid/female, respectively.

Data in Table (2) indicate that there was a reduction in hatchability percentages by using ergosterol-propyl ester compound compared to control (-ve and +ve) which give $98.0 \pm 44$ and $97.3 \pm 44 \%$, respectively. Ergoserol-propyl ester compound showed highly significant reduction in hatchability percentages and recorded $82.9 \pm 1.04 \%(\mathrm{~F}(2,27)=145.2, P<0.001)$.

Deformations of larvae, pupae and adult malformations

Based on the external morphological characters of deformed larvae, pupae and malformations of adult were illustrated in Figure 3 and 4 . Ten percent 
Table (2): Biological aspects of $S$. littoralis adults resulted from treated $4^{\text {th }}$ instar larvae with isolated compound.

\begin{tabular}{|c|c|c|c|c|c|c|c|c|}
\hline \multirow{3}{*}{ Treatments } & \multirow{3}{*}{$\underset{\%}{\text { Emergence }}$} & \multicolumn{5}{|c|}{ Longevity / days \pm SD } & \multirow{3}{*}{ Fecundity } & \multirow{3}{*}{$\begin{array}{c}\text { Hatchabilit } \\
\text { y } \%\end{array}$} \\
\hline & & \multirow[b]{2}{*}{ Male } & \multicolumn{4}{|c|}{ Female at different period } & & \\
\hline & & & $\begin{array}{c}\text { Pre- } \\
\text { oviposition }\end{array}$ & Oviposition & $\begin{array}{c}\begin{array}{c}\text { Post- } \\
\text { oviposition }\end{array} \\
\end{array}$ & Female & & \\
\hline $\begin{array}{l}\text { Control } \\
\text { (-ve) }\end{array}$ & 98 & $9.36 \pm 0.06^{\mathrm{a}}$ & 2 & 4.06 & 2 & $8.06 \pm 0.03$ & $2016.7 \pm 27.06^{a}$ & $98 \pm 0.44^{\mathrm{a}}$ \\
\hline $\begin{array}{l}\text { Control } \\
\text { (+ve) }\end{array}$ & 98 & $9.4 \pm 0.05^{\mathrm{a}}$ & 2 & 3.92 & 2.04 & $7.96 \pm 0.08$ & $1989.1 \pm 32.63^{a}$ & $97.3 \pm 0.44^{\mathrm{a}}$ \\
\hline $\begin{array}{l}\text { Ergosterol- } \\
\text { propyl } \\
\text { ester }\end{array}$ & 90 & $8.83 \pm 0.12^{b}$ & 2.1 & 3.67 & 2.26 & $8.03 \pm 0.03$ & $1653.1 \pm 50.23^{b}$ & $82.9 \pm 1.04^{b}$ \\
\hline L.S.D. $\mathbf{0 . 0 5}_{1}$ & & 0.297 & & & & 0.199 & 110.127 & 2.051 \\
\hline$P$ & & 0.005 & & & & $0.500 \mathrm{~ns}$ & 0.001 & 0.001 \\
\hline $\mathbf{F}$ & & 13.56 & & & & 0.777 & 28.448 & 145.286 \\
\hline
\end{tabular}

${ }^{\dagger} \mathrm{Control}(-\mathrm{ve})$, (treated with $\mathrm{H}_{2} \mathrm{O}$; Control (+ve), treated with acetone; Treatment at the level of $\mathrm{LC}_{50}$.

Data expressed as Mean \pm Standard Error (SE);

Means with the same letter for each column are not significantly different at $P<0.05$.

of deformed larvae were appeared after treatment with ergosterol-propyl ester and six percent of forms deformations are appeared on pupae. Meanwhile, malformed adults recorded $4 \%$.

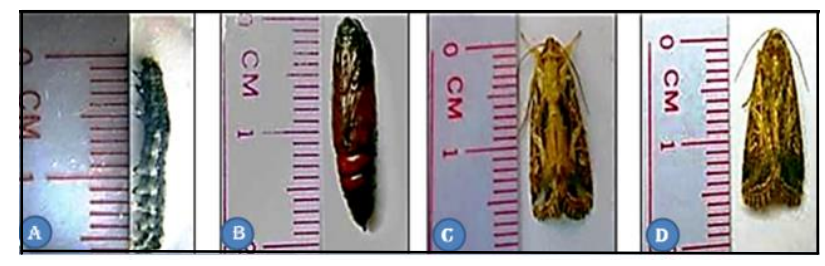

Figure (3): Illustrated normal larval, pupal and adult stages of $S$. littoralis. (A), the $4^{\text {th }}$ larval instar; (B), Pupae,(C), Adult moth male; (D), Adult female.

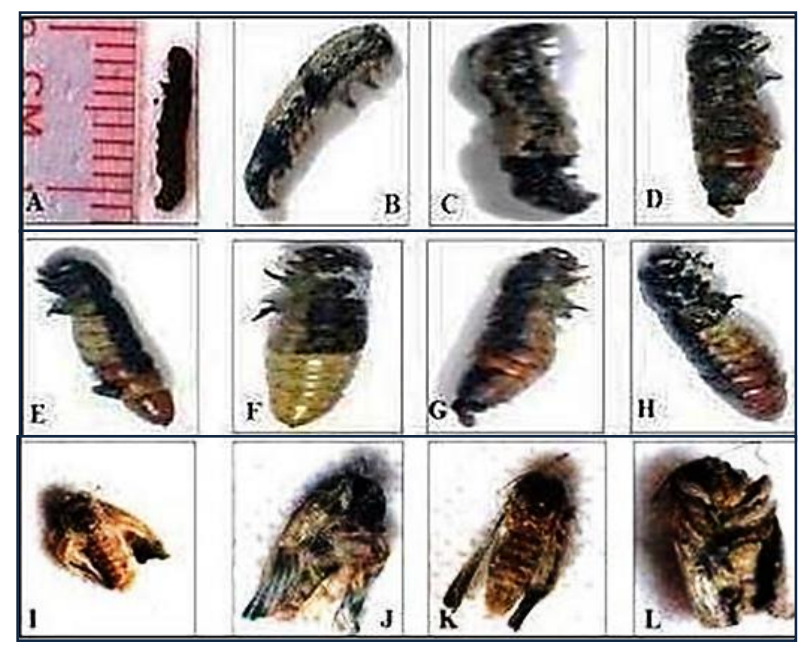

Figure (4): Illustrated larval, pupal and adult stage of $S$. littoralis after treatment with Ergosterol propyl-ester. (A): Dwarf larvae; (B, and C), Unable to discarding the old cuticle; (D, and E), Larval - Pupal intermediates; (F, G, and H), Pupal - Larval intermediates; (I, J, K, and L), illustrated adult malformation.

\section{Ultrastructure studies on $\boldsymbol{S}$. littoralis larvae}

Ultrastructure studies showed that $\mathrm{LC}_{50}$ of the isolated compound ergosterol propyl-ester caused pathological changes in the cuticle and muscles in the $4^{\text {th }} S$. littoralis larval compared with (+ve control).

\section{Cuticle layer}

In control cuticle, normal parallel running chitin microfilaments associate with proteins forming sheets called laminae, to accord exoskeleton elasticity and constitute the pro-cuticle that lies between the protein rich epi-cuticle and the apical plasma membrane. However, the epi-cuticle is often no laminae and is distinguishable in oblique sections, Plate (1A). In case of ergosterol-propyl ester application, the epi-cuticle and the pro-cuticle cannot be distinguished and chitin microfilament is absent and loses its layered organization, Plate (1B).

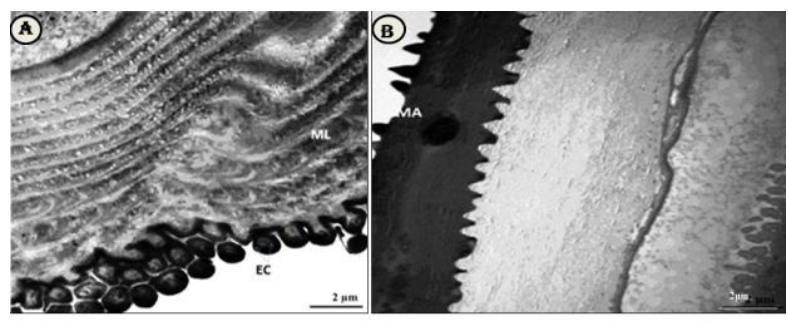

Plate (1): Electron micrographs (EM) illustrating transverse section in the cuticle of Spodoptera littoralis $4^{\text {th }}$ instar larvae [1200X].(A), Control +ve (using acetone only); (B), Treated with ergosterolpropyl ester.[EC, Epicuticle; MA, Microfilaments Absent; ML, Microfilaments lammina].

\section{Muscles}

The transverse section in muscle cells clarified that, in normal muscle of untreated larvae there are typically greater number of mitocondria and they tend to be distributed in association with the contractile filaments, 
Plate (2A). In case of ergosterol-propyl ester treatment the mitochondria became smaller in size, more spherical and more separated from the myofilmentes segementaly and the latter more separated from each other leaving wide spaces in beetwen, Plate (2B).

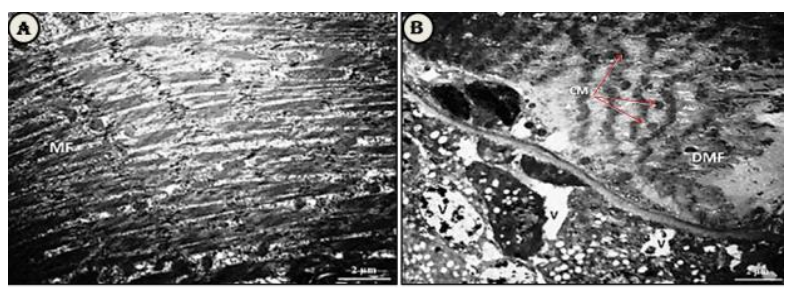

Plate (2): EM. illustrating transverse section in muscle of $S$. littoralis $4^{\text {th }}$ instar larvae $[1200 X] .(A)$, Cont. + ve of the $4^{\text {th }}$ larvae of $S$. [CM, Condensed Mitochondria; DMF, Disentgration Muscle fiber; MF, Muscle Fiber; V, Vacuoles].

\section{Biochemical response of $4^{\text {th }}$ instar larva of $S$. littor- alis to ergosterol-propyl ester}

The changes in some enzymatic activities like transaminase, chitinase of the $4^{\text {th }}$ instar larvae of $S$. littoralis as responses with $\mathrm{LC}_{50}$ of ergosterol-propyl ester after $72 \mathrm{hrs}$ post-treatments.

\section{Alanine aminotransferase (ALT)}

Ergosterol-propyl ester compound caused insignificant reduction in ALT enzyme activity as compared to controls Table (3). Ergosterol-propyl ester recorded $33.72 \pm 1.84 \mu$ g Pyr. /g.b.w./min. compared to controls (ve and +ve) which recorded $37.99 \pm 0.32$ and $37.96 \pm 0.41 \mu \mathrm{g}$ Pyr./g.b.w./min, respectively. In table (3) F $(2,6)=4.917, P<0.054^{\mathrm{ns}}$.

\section{Aspartate aminotransferase (AST)}

Data indicats that the ergosterol-propyl ester compound caused a significant increase in AST activities as compared to -ve and +ve controls. This decrease recorded $20.63 \pm 0.37 \mathrm{mg}$.Pyr./g.b.w./min, compared to controls (-ve and +ve) which recorded $19.79 \pm 0.07$ and $19.49 \pm 0.17 \mu \mathrm{g}$. Pyr. /g.b.w. /min, respectively Table $(3),(\mathrm{F}(2,6)=6.02, P<0.036)$.

\section{Chitinase enzyme}

The statistical analysis shows highly significant reduced in the chitinase activities by ergosterol-propyl ester compound (57.14 $\pm 0.08 \mu$ g.N-acet. /g.b.w. /min.) as compared to for -ve and +ve controls (65.98 \pm 0.11 and $64.98 \pm 0.15 \mu$ g.N-acet./g.b.w./min.), respectively. In table $(3),(\mathrm{F}(2,6)=15.13, P<0.001)$.

Table (3): Changes in the transaminase enzymatic activities and chitinase of the $4^{\text {th }}$ instar larva of S. littoralis treated with ergosterol-propyl ester.

\begin{tabular}{|c|c|c|c|}
\hline Treatments & $\begin{array}{c}\text { Transaminase enzymes(ALT) } \\
(\mu \mathrm{g} . \text { Pyr. / g.b.w. } / \mathrm{min})\end{array}$ & $\begin{array}{c}\text { Transaminase enzymes(AST) } \\
(\mu \mathrm{g} . \text { Pyr./g.b.w. /min })\end{array}$ & 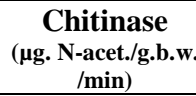 \\
\hline $\begin{array}{l}\text { Control } \\
\text { (-ve) }\end{array}$ & $37.99 \pm 0.32$ & $19.79 \pm 0.07^{b}$ & $65.98 \pm 0.11^{a}$ \\
\hline $\begin{array}{l}\text { Control } \\
\text { (+ve) }\end{array}$ & $37.96 \pm 0.41$ & $19.49 \pm 0.17^{b}$ & $64.98 \pm 0.15^{b}$ \\
\hline $\begin{array}{l}\text { Ergosterolp } \\
\text { ropyl ester }\end{array}$ & $33.72 \pm 1.84$ & $20.63 \pm 0.37^{a}$ & $57.14 \pm 0.08^{c}$ \\
\hline L.S.D 0.05 & 3.835 & 0.838 & 0.43 \\
\hline$P$ & $0.0544^{\mathrm{ns}}$ & 0.0368 & 0.001 \\
\hline $\mathbf{F}$ & 4.917 & 6.023 & 15.13 \\
\hline
\end{tabular}

${ }^{\dagger}$ Control (-ve), (treated with H2O; Control (+ve), treated with acetone; AlltTreatment at the level of $\mathrm{LC}_{50}$.

Data expressed as Mean \pm Standard Error (SE);

Means with the same letter under each variety sharing are not significantly different at $P<0.05$.

\section{DISCUSSION}

Based on $\mathrm{LC}_{50}$ values, the type of solvent used for extraction seems to be considerably effect the toxicological activity of $R$. angustifolia. The acetonic extract was more effective than hexane and ethyl alcoholic extracts. These results were in agreement with Hafez (2001) who tested petroleum ether and acetonic extracts of Iberis amara seeds and Antholyza aehtiopica scale leaves against $S$. littoralis and Nassar et al., (2015) when studied the toxic effects of acetonic, hexane and alcoholic extracts of the aerial parts of Ipomea carnea against the $4^{\text {th }}$ instar larvae of $S$. littoralis.

Ergosterol-propyl ester was isolated and purified from the acetonic extract of $R$. angustifolia using thin layer chromatography and identified by Infra-Red spectrophotometer and Mass Spectrum. Fragmentation data were found typical for compounds with ergosterol propyl ester (Zaretskii, 1976 and El Shafeiy 2011). Furthermore, many scientists had been isolated ergosterol derivatives which naturally produced in some plants and fungi. Rocha et al., (2014) isolated five steroids from the stems of Rauia nodosa (Rutaceae) sistostenone, stigmastenone, sitosterol, stigmaasterol and ergosterol peroxide, one coumarin, O-geranylosthenol and three alkaloids, N-methylflindersine , zantobungeanine and veprissine.

Toxicity experiment shows that ergosterol-propyl ester compound is effective against 4th instar larvae of S. after $72 \mathrm{hrs}$ of treatment.The toxicity of erogosterolpropyl ester may be attributed with their different activities.

The presented data revealed that the biological 
activities on successive stages of $S$. littoralis were severely affected by varying degree due to feeding newly molted $4^{\text {th }}$ instar larvae with $\mathrm{LC}_{50}$ of the ergosterol-propyl ester compared to (-ve and +ve) controls. As a general trend, the statistical analysis revealed that, there are no significant difference between (-ve and +ve) controls against the $4^{\text {th }} S$. littoralis larvae in all tested biological parameters. Thus, the effects against $S$. littoralis larvae may attribute to the active compound in the acetone extract of $R$. angustifolia leaves.

Many authors revealed the same biological results when tested many plant extracts against $S$. littoralis larvae. Likewise, EL-Kholy et al., (2014) who recorded that the increased in the larval mortality after feeding the 2nd instar larvae of $S$. littoralis on crud extracts from leaves of three plants (i.e. Damsissa, Camphor and Datura). The effect of ethanolic extract of Zingiber officinali at concentrations $(2,4$ and $6 \%)$ on the $3^{\text {rd }}$ and $6^{\text {th }}$ larval stage of $S$. littoralis. Increase the mortality percentages and prolonged durations of larval stages Ali et al., (2017). Also, Salama (2015) the acetonic extract of I. carnea and chlorpyrifos against $S$. littoralis. Reduese adult emergence percentages and fecundity after treated with I. carnea extract.

Fourty-eight hours of feeding on castor bean oil leaves treated with $\mathrm{LC}_{50}$ of ergosterol-propyl ester compared to controls resulteing larvae not able to complete the molting process and subsequently died. Salama (2015) reached to the same conclusion when tested two different concentrations of I. carnea against $4^{\text {th }}$ instar larvae of $S$. littoralis. The reason of deformations and malformations may be as a result of reduction or elevation in transaminase enzymes. The aminotransferases, especially ALT is one of the components of oxidative metabolism of protein which in certain insect is utilized during the initial periods of flights.

In the current study, ultrastructure studies were done using TEM to encourage the role of the new isolated compound ergosterol-propyl ester in damage of cuticle and muscles. The tested compounds were characterized by a mode of action on the cuticle similar to that's of Juvenile Hormones compound and their activity have characteristics resembling to Insect Growth Regulator. Khedr et al., (2015) evaluated the ultrastructural changes in the $4^{\text {th }}$ larval instar cuticle of $S$. littoralis as a result of application with the acetonic extract of Ipomea carnea compared to traditional insecticide (chlorpyrifos) such as cuticle being edges and separation of endocuticle from epicuticle.

Also, the extracted component application on larvae caused alterations in myofilaments striation which may be due to mitochondrial deformations and lead to block the energy supply to muscle needed for mechanical activities. Many researchers are coincides with these results when applied extracted components on S. littoralis larvae, Sabry (2009) and Sakr and Roshdy (2015) evaluated the histological damage in muscles of $S$. littoralis larvae caused by Hyptis brevipes methanol extract.
Biochemical parameters in organisms exposed to toxicants considered as sensitive index to monitor disturbances occurred inside the organism. Biochemical parameters are important diagnostic tools to evaluate the effects of stressors. The amino transferases enzymes constitute a group of enzymes, which catalyze the interconversion of amino acids and $\alpha$ ketoacids by transfer of amino groups (Kachmar 1970). They have an important role in linking amino acids and carbohydrate metabolism, being an essential group of enzymes in the gluconeogenesis pathway. AST and ALT in insects are the most active transaminase enzymes (Carbetree and Newssholom 1970). The aminotransferase, especially ALT is one of the components of oxidative metabolism of protein, which in certain insects is utilized during the initial periods of flights (Bursell 1963). Data obtained revealed a decrease of ALT and an increase in AST activities in the supernatant of $S$. littoralis in all treatments compared to (-ve and +ve) controls. The greater and continuous release of AST might be due to the necessity of enhancing domination of aspartic acid for the process of gluconeogenesis especially under conditions of impaired carbohydrate metabolism. These results were strengthened by El-lakwah (2018) who studied the effect of Ocimum sanctum leaves extract against the 2 nd and the $4^{\text {th }}$ instar larvae of $S$. littoralis. On the other hand, Salama (2015) found significant elevation in ALT and AST enzymes in $4^{\text {th }}$ instar larvae of $S$. littoralis treated with $\mathrm{LC}_{50}$ of the acetonic extract of Ipomea carnea.

Chitinase are generally found in organisms that either needs to reshape their own chitin or dissolve and digest the chitin of insect's chitin. Data indicate that all the treatments caused a decrease in chitinase activities as compared to (-ve and +ve controls). Additionally, Taira et al., (2002) reported that the roles of chitinase are usually part of the digestive tract. Insects and crustaceans, chitinase are associated with the need for partial degradation of old cuticle. Chitinase have been implicated in plant resistance against fungal pathogens because of their inducible nature and antifungal activities in vitro. These results were in agreement with; Sabry (2018) evaluated the efficacy of the Taxodium distichum (L.) ethanol extract fruits and the chitin synthesis inhibiting insecticide, lufenuron on the $4^{\text {th }}$ instar of larvae $S$. littoralis.

\section{CONCLUSION}

The presented data showed the importance of naturally origin compounds especially those derived from plants. It also indicates ergosterol-propyl ester that isolated from the acetonic extract of Ruta angustifolia has the possibility to play an important role as larvicidal action against $S$. littoralis.These findings are useful and important to inegrate these compounds into IPM programs for control $S$. littoralis. further studies are necessary to evaluate the costefficiency of this compound on wide range of pests as alternative biocide in pest control. 


\section{REFERENCES}

ABBOTT, W. S. 1925. A method of computing the effectiveness of an insecticide. J. Econ. Entomol., 18 (2): 265-267.

ALI, A. M., D. S. MOHAMED, E. H. SHAURUB, AND A. M. ELSAYED. 2017. Antifeedant activity and some biochemical effects of garlic and lemon essential oils on Spodoptera littoralis (Boisd.). Journal of Entomology and Zoology Studies, 5(3): 1476-1482.

BAKR, E. 2000. LdP Line. (visited December, 1 2019) http://www.ehabsoft.com/ldpline.

Bursell, E. 1963. Aspects of the metabolism of amino acids in the tsetse fly Glossina (Diptera). J. Insect Physiol., 9: 439-452.

CARBETREE, B. J., AND E. A. NEWSSHOLME. 1970. The activity of protein dehydrogenase and aspartate oxoglutarate amino transferase in some insect flight muscles. Biochem.J., 117:1019-1021.

COSTAT STATISTICAL SOFTWARE. 2005. Microcomputer program analysis (version, 6. 311. Co. Hort Software, Monterey, California).

ELSHAFEIY, S. N. 2011. Latent biochemical and biological activities of some natural products compared to synthetic compounds against some pests. Ph. D. Fac Agric. Zagazig Univ., pp.163.

EL-DEFRAWI, M. E., A. TOPPOZADA, N. MANSOUR, AND M. ZEID. 1964. Toxicological studies on the Egyptian cotton leafworm, Prodenia litura. Susceptibility of different larval instars of prodenia to insecticides. J. Econ. Entomol., 57: 591-593.

EL-KHOLY, R. M. A., M. M. M. EL-BAMBY, M. F. EL-TAWIL, AND W. L. ABOUAMER. 2014. Effect of three plant extracts on some biological aspects of cotton leafworm, Spodoptera littoralis (Boisd.) Middle East Journal of Applied Sciences, 4(2): 243-251.

El-LAKWAH, S. F. 2018. Effect of Ocumum sanctum against biochemical aspects Spodoptera littoralis (Lepidoptera: Noctuidae) larvae. Egypt. J. Plant Prot. Res. Inst., 1(2): 112-121.

EL-SAYED, E. M. A. 2008. Studies on insect cuticle degrading enzymes by some microorganisms and their role in bio control on insects, M. Sc. Thesis. Fac. of Sci., Zagazig Univ. pp 281.

GONZALEZ-TRUJANO, M. E., D. CARRERA, R. VENTURA-MARTINEZ, E. CEDILLOPORTUGAL AND A. NAVARRETE. 2006. Neuropharmacological profile of an ethanol extract of Ruta chalepensis L. in mice. J. Ethnopharmacol., 106: 129-135.

HAFEZ, A.A. 2001. Anti-insect properties of the Iberis amara Linn. and Antholyza aethiopica Andr., extract against the cotton leafworm, Spodopetra littoralis (Boisd.) (Lepidoptera: Noctuidae). Practice oriented results on use of plant extracts and pheromones in ingrate and biological pest control, Cairo, Egypt, February, 10-11.
HIKAL, W. M., R. S. BAESHEN AND H. A. H. SAID-ALAH 2017. Botanical insecticide as simple extractives for pest control. Cogent Biology, 3(1): 140-174.

KACHMAR, J. F. 1970. Enzymes. In: Tietz, N.W. (Ed.), Fundamentals of clinical chemistry, W. B. Saunders Company., Philadelphia. London. Toronto. pp. 441.

KHEDR, M. M. A. 2002. Effect of some plant extracts and insect growth regulators applied to control cotton leafworm on honeybees; Apis mellifera L. M.Sc. Thesis, Fac. of Agric. Zagazig Univ, Egypt. pp. 204.

KHEDR, M. M. A., H. M. SABRY, AND M. G. SALAMA. 2015. Ultrastructure and biochemical alterations of cotton leafworm, Spodoptera littoralis treated with Ipomea carnea extract. Egypt. J. Agric. Res., 93 (1): 609.

KIRCHNER, J. C. $1967 . \quad$ "Thin-Layer chromatography". John Wiley \& Sons New Yurok, London. Sydny, pp.174.

MERDAN, A. H. 1968. Studies on the effect of certain chemical entomopathogens on some cotton worms in Egypt. M. Sc. Thesis, Fac. of Sci. Cairo Univ., Egypt.

MONEAL, J., AND E. T. REESE. 1969. The chitinase of Serratia marcescens. Canadian Journal of Microbiology, 15 (7): 689-696.

MOSS G. P. 1992. Enzyme nomenclature. San Diego, $\mathrm{CA}$ and Academic Press.

NASSAR, M. I., M. T. TAHA, H. M. I. MEAD, AND M. G. M. SALAMA. 2015. Evaluation of Ipomoea carnea extracts and chlorpyrifos insecticide against the cotton leafworm, Spodoptera littoralis (Boisd.). New Trends and Issues Proce on Humanities and Social Sci., 5(4):1-11.

RAGHAV, S. K., B. GUPTA, C. AGRAWAL, K. GOSWAMI, AND H. R. DAS. 2006. Antiinflammatory effect of Ruta graveolens in murine macrophage cell. J. Ethnopharmacol., 104: 234239.

REITEMAN, S. M. D., AND S. FRANKEL. 1957. A colorimetric method for the determination of serum glutamic oxaloacetic acid and glutamic pyruvic transaminase. Ann. J. Clin. Pathol. 28(6): 56-62.

ROCHA, M. R., J. J. SOUZA, L. T. BARCELLOS, N. M. R. ANNA, R. B. FILHO, AND I. J. C. VIEIRA. 2014. A Novel 3, 9-(1, 2, 3-Trioxocine)-Type Steroid of Rauia nodosa (Rutaceae).19: 1463714648.

SABRY, H. M. 2009. Using some alternative compounds for controlling some cotton pests in sharquia governorate. M. sc. Thesis, Fac. Sci. Zagazig Univ. pp 205.

SABRY, H. M. 2018. Scanning electron microscopy and biochemical studies on Spodoptera littoralis larvae following treatments with ethanolic extract of Taxodium distichum and Lufenuron. J. Plant Prot. and Path., Mansoura Univ., 9: 131-138.

SAKR, H. H. AND S. H. ROSHDY. 2015. Effect of Hyptis brevipes (Lamiaceae) methanol Extract on 
Spodoptera littoralis (Lepidoptera: Noctuidae) larvae. Research Journal of Pharmaceutical, Biological and Chemical Sciences, 6(6): 651- 658.

SALAMA, M. G. 2015. Bioactivity of some botanical extracts from Ipomea carnea Jace (Convolvulaceae) and ultrastructure studies on the cotton leafworm, Spodoptera littoralis (Boisduval) (Lepidoptera: Noctuidae). M.Sc. Thesis, Fac. of Science, AlAzhar Univ, pp. 115.

SHINDIA, A. A., M. I. ABOU HAWA AND K. S. M. SHALABY. 2001. Fungal degradation of shrimp shell chitin waste and effect of culture conditions on the production of chitinase by a potent Trichoderma viride. Egypt. J. of Microbiol., 36 (2): 119-134.

SNEDECOR, G. W., AND G. W. COCHRAN. 1980. Statistical methods (2nd Ed. Iowa State Univ. Press Iowa, USA 97.

STELLA, J. AND M. RICHARDSON. 2018. Cytotoxic investigation of crude extracts and isolated compounds from Ruta angustifolia Pers. leaves and effects of chalepin on the expression of selected cancer-related proteins in human lung carcinoma cells A549 / Jaime Stella Moses Richardson. PhD thesis, University of Malaya.

SUN, Y. P. 1950. Toxicity index-An Improved method of comparing the relative toxicity of insecticides $\mathrm{J}$. Econ. Entomol., 43(1): 24-53.

TAIRA, T., T. QHNUMA, T. YAMAGAMI, AND M. ISHIGURO. 2002. Antifungal activity of rye, Secale cereale seed chitinase the different binding manner of class I and class II chitinase to fungal cell wall. Biosci. Biotechnol. Biochem., 66:970977.

WAHYUNI, T.S., A. WIDYAWARUYANTI, M. I. LUSIDA, A. FUAD, H. FUCHINO, N.KAWAHARA, Y. HAYASHI, C. AOKI, AND H. HOTTA. 2014. Inhibition of hepatitis $C$ virus replication by chalepin and pseudane IX isolated from Ruta angustifolia leaves. Fitoterapia, 99: 27683.

ZARETSKII, Z. V. 1976. Mass spectrometry of steroids, Wiley Publishing Co. New York, pp.: 182.

\title{
التأثيرات الحيوية لمركب الايرجوستيرول بروبيل ايستر المستخلص من نبات السذاب المصري على دودة ورق القطن (سبودويترا ليتور اليس) من فئين
}

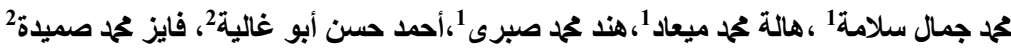

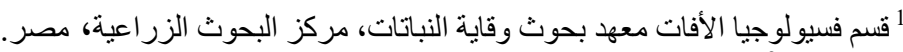

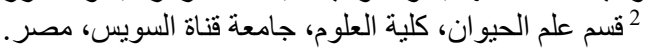

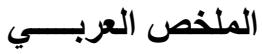

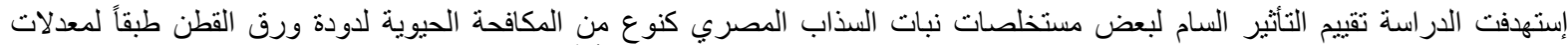

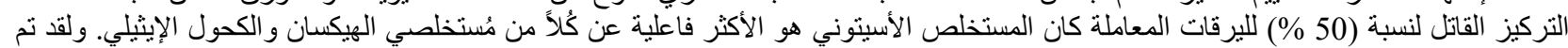

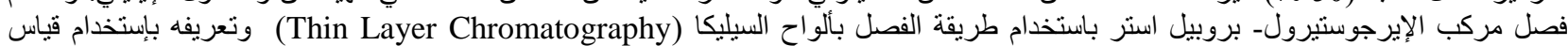

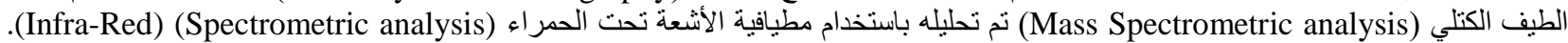

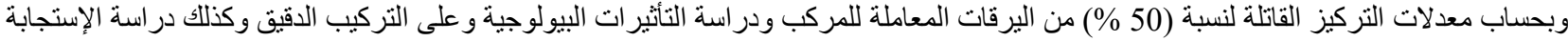

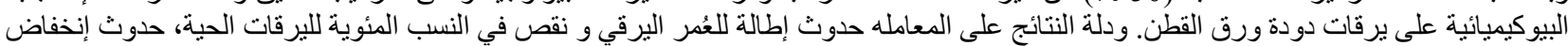

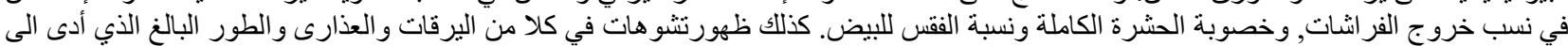

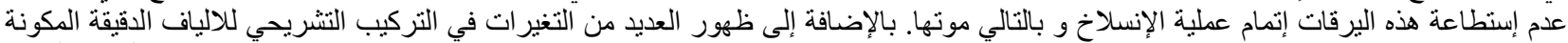

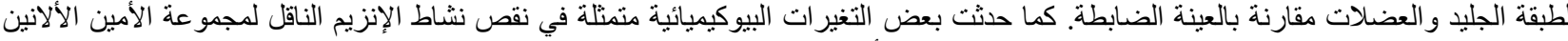
و انزيم الكيتينيز وزيادة في نشاط الإنزيم الناقل لمجمو عة الأمين الإسبارنات (ALT) 